\title{
THE APPLICATION OF THE ECHR IN THE DOMESTIC SYSTEMS*
}

\author{
ANDREA CALIGIURI ${ }^{* *}$ and NiCOLA NAPOLETANO ${ }^{* * *}$
}

\section{Status and Effects of the ECHR on Domestic Legal Systems}

\subsection{Overview of the Status and Impact of the ECHR in the Contracting Parties' Legal Systems}

According to the European Court of Human Rights (ECtHR), unlike classic international treaties, the European Convention of Human Rights (ECHR) "comprises more than mere reciprocal engagements between contracting States. It creates, over and above, a network of mutual, bilateral undertakings, objective obligations which, in the words of the Preamble, benefit from a "collective enforcement". From Article 1 of the Convention, in particular, it follows that "the primary responsibility for implementing and enforcing the rights and freedoms guaranteed by the Convention is laid on the national authorities", ${ }^{2}$ and especially on national courts, whose role in making the ECHR effective in domestic legal orders is of the utmost importance. $^{3}$

By ratifying the ECHR, the Contracting States undertake to ensure that their domestic legislation is compatible with it. ${ }^{4}$ So, a breach of the ECHR can result from the mere existence of a law which introduces, directs or authorizes measures incompatible with the minimum standard of protection guaranteed by the Convention. Nonetheless, in order to establish that this minimum standard has been violated, reference should be made to the manner national authorities interpret and apply in concreto the Convention. The absence of a law expressly prohibiting a violation is not sufficient in itself to establish a breach since such a prohibition does not represent the sole method of securing the enjoyment of the rights and

${ }^{*}$ While the authors equally share the responsibility for the entire essay, section 1 is by Nicola Napoletano and section 2 is by Andrea Caligiuri.

${ }^{* *}$ Researcher in International Law, University of Macerata.

*** Researcher in International Law, University Unitelma Sapienza (Rome)

${ }^{1}$ See ECtHR, Ireland v. the United Kingdom, Application No. 5310/71, Judgment of 18 January 1978, para. 239.

${ }^{2}$ See ECtHR, Sürmeli v. Germany [GC], Application No. 75529/01, Judgment of 8 June 2006, para. 97.

${ }^{3}$ See Stone Sweet and Keller, "The Reception of the ECHR in National Legal Orders", in KeLLER and Stone Sweet (eds.), A Europe of Rights. The Impact of the ECHR on National Legal Systems, Oxford, 2008, p. 3 ff.

${ }^{4}$ This principle has been held by the ECtHR on many occasions; see, recently, ECtHR, Paksas v. Lithuania [GC], Application No. 34932/04, Judgment of 6 January 2011, para. 119. 
freedoms guaranteed. ${ }^{5}$ Moreover, as the ECHR guarantees the availability at national level of a remedy to enforce the substance of the Convention rights and freedoms, ${ }^{6}$ Contracting States must provide all necessary remedies under domestic law in order to prevent alleged violations of the Convention or their continuation, or to provide adequate redress for any violation already occurred. ${ }^{7}$

The ECHR leaves it to the States parties to decide how to comply with their duty to observe the provisions of the Convention. As stated by the ECtHR, indeed, the ECHR does not lay down for the Contracting States "any given manner for ensuring within their internal law the effective implementation" of any of the rights and freedoms guaranteed. ${ }^{8}$ Moreover, in the James and Others and in the Lithgow and Others cases, ${ }^{9}$ the ECtHR held that States are not requested to incorporate the Convention into domestic law, but that "the substance of the rights and freedoms set forth must be secured under the domestic legal order, in some form or another, to everyone within the jurisdiction of the Contracting States". ${ }^{10}$

The mere incorporation of the ECHR into a domestic legal system is, therefore, neither able to solve all the problems related to its application nor to guarantee the faithful and effective application of the Convention in the domestic legal system of the Contracting States. It is important, therefore, to analyze the status and the effects of the ECHR in domestic legal orders, assuming that the strength of the impact of the Convention on national legal system ${ }^{11}$ mainly depends on two aspects: 1) the position of the ECHR in the domestic hierarchy of sources of law, that is to

${ }^{5}$ See ECtHR, Ireland v. the United Kingdom, cit. supra note 1, para. 240.

${ }^{6}$ The mechanism of complaint to the ECtHR is thus subsidiary to national systems safeguarding human rights. According to the ECtHR, the subsidiary character of the Convention is articulated in Article 13 and Article 35(1) ECHR (see ECtHR, M.S.S. v. Belgium and Greece [GC], Application No. 30696/09, Judgment of 21 January 2011, para. 287; Scordino v. Italy (No. 1) [GC], Application No. 36813/97, Judgment of 29 March 2006, para. 140; Cocchiarella v. Italy [GC], Application No. 64886/01, Judgment of 29 March 2006, para. 38; and Kudta v. Poland [GC], Application No. 30210/96, Judgment of 26 October 2000, para. 152). Therefore, subsidiarity can be considered as a basic principle in the process of implementation of the Convention. On this point, see PETzOLD, "The Convention and the Principle of Subsidiarity", in MACDONALD, MAtscher and Petzold (eds.), The European System for the Protection of Human Rights, The Hague, 1993, p. 59 ff.

${ }^{7}$ See ECtHR, Sürmeli v. Germany [GC], cit. supra note 2, para. 98-99

${ }^{8}$ See ECtHR, Swedish Engine Drivers Union, Application No. 5614/72, Judgment of 6 February 1976, para. 50.

${ }^{9}$ See ECtHR, James and Others v. the United Kingdom, Application No. 8793/79, Judgment of 21 February 1986, para. 84, and Lithgow and Others v. the United Kingdom, Application Nos. 9006/80, 9262/81, 9263/81, 9265/81, 9266/81, 9313/81, 9405/81, Judgment of 8 July 1986, para. 205.

${ }^{10}$ See also ECtHR, Soering v. the United Kingdom, Application No. 14038/88, Judgment of 7 July 1989, para. 120.

${ }^{11}$ See BlackBURN and POLAKIEWICZ (eds.), Fundamental Rights in Europe. The European Convention on Human Rights and Its Member States, 1950-2000, Oxford, 2001; KELLER and Stone SweEt (eds.), cit. supra note 3; MARTinico and Pollicino (eds.), The National Judicial 
say whether it has a supra-legislative status in domestic legal orders and, therefore, prevails over conflicting national laws enacted before or after the ratification and the entry in to force of the Convention itself; and 2) the self-executing character of the ECHR rules and the possibility that the European Convention rights be directly enforced by national courts. ${ }^{12}$

There are different approaches and a variety of constitutional provisions concerning the status, the application and the effects of the ECHR in the domestic legal orders. Moreover, the direct application of the European Convention provisions at national level, ${ }^{13}$ the judicial enforcement of conventional rights and the judicial review of legislative and executive acts with reference to the ECHR differ from one State to another. ${ }^{14}$ In addition, no express obligation to give direct effect to the ECHR within domestic legal orders is included in the text of the Convention.

In the majority of Contracting Parties of Central and Eastern Europe, as well as in the Netherlands, ${ }^{15}$ following a monist approach ${ }^{16}$ that considers international and domestic law as part of the same legal system, the Convention substantive rights are self-executing and enjoy supremacy over national legislation. The ECHR pro-

Treatment of the ECHR and EU Laws. A Comparative Constitutional Perspective, Groningen, 2010.

${ }^{12}$ See CATALDI, "La natura self-executing delle norme della CEDU e l'applicazione delle sentenze della Corte europea negli ordinamenti nazionali", in CALIGIURI, CATALDI and NAPOLETANO (eds.), La tutela dei diritti umani in Europa tra sovranità statale e ordinamenti sovranazionali, Padova, 2010, p. $565 \mathrm{ff}$.

${ }^{13}$ Concerning the literature about the direct applicability of the ECHR in the Contracting States, see CATALDI, "Convenzione europea dei diritti dell'uomo e ordinamento italiano. Una storia infinita?", DUDI, 2008, p. 321 ff., at p. 328, notes 18, 19 e 20.

${ }^{14}$ For practical reasons, it is not possible to cover all of the Contracting Parties' domestic legal orders; only some of them have been analysed taking into account the different legal traditions.

${ }^{15}$ See DE Wet, "The Reception Process in the Netherlands and Belgium", in Keller and STONE SwEET (eds.), cit. supra note 3, p. 229 ff., p. 235 ff.: "The relationships between domestic and international law in the Netherlands is characterized by a monist character [Article 93 of the Dutch Constitution] and the supreme position of international law in the Dutch constitutional order [Article 94 of the Dutch Constitution]".

${ }^{16}$ As far as the relationship between the domestic and international legal systems is concerned, France can be considered "formally" monist. According to Article 55 of the French Constitution, the ECHR has been automatically incorporated into the domestic legal order since its publication and it is directly applicable. Regarding the rank in the hierarchy of sources of laws, international treaty law has supra-legislative, but infra-constitutional status. The Constitutional Council has the sole competence to review the constitutionality of law before they enter into force. The Council of State and the Court of Cassation can review the compatibility of national legislation with the ECHR and, if it is inconsistent, they can disapply domestic law. See LAMBERT ABDElgawad and WeBer, "The Reception Process in France and Germany", in Keller and StOne SweEt (eds.), cit. supra note 3, p. 107 ff., at p. 115 ff. See also SOREL, "La France et la Cour européenne des droits de l'homme, variations sur les amours d'un couple tumultueux", in CALIGIURI, CATALDI and NAPOLETANO (eds.), cit. supra note 12, p. 621 ff.; FARTUNOVA, "Report on France", in MARTINICO and POLliCinO (eds.), cit. supra note 11, p. 205 ff. 
visions create enforceable rights for individuals at level of statutory law or constitutional law, or at an intermediate level above statutes but below the Constitution, which can be judicially enforced even in the absence of any further domestic measure for implementation.

In countries that have ratified the Convention more recently, and specifically in the vast majority of the new Member States of Central and Eastern Europe, the ECHR has been automatically incorporated through the reference operated by a constitutional rule, which usually recognizes a super-legislative rank to international treaties in the domestic hierarchy of sources of law. For instance, the ECHR enjoys a particular status within the Bulgarian legal order as specified in the Constitution of 1991. Its incorporation in the Bulgarian legal system is expressly stated in Article 5(4) of the Constitution, which reads: "International treaties which have been ratified in accordance with the constitutional procedure, promulgated and having come into force with respect to the Republic of Bulgaria, shall be part of the legislation of the State. They shall have primacy over any conflicting provision of the domestic legislation". According to the aforementioned Article 5(4), in the domestic hierarchy of source of law the ECHR is placed above statutes and laws but below the Constitution. Article 5(1) of the Constitution, indeed, states that the "Constitution shall be the supreme law, and no other law shall contravene it". ${ }^{17}$ Another example is the 1991 Constitution of Romania ${ }^{18}$ which provides that " $[\mathrm{t}]$ reaties lawfully ratified by Parliament shall form an integral part of the domestic legal order" (Article 11(2)). Moreover, according to Article 20 of the Romanian Constitution:

"[The] constitutional provisions on citizens' rights and liberties shall be interpreted and applied in accordance [...] with the covenants and other treaties to which Romania is a party. [...] In the event of conflict between the covenants and treaties on fundamental human rights to which Romania is a party and domestic laws, the international instruments shall prevail".

As far as the Republic of Moldova is concerned, Article 4 of the Constitution reads:

"Constitutional provisions for human rights and freedoms shall be
understood and implemented in accordance [...] with other conven-
tions and treaties to which the Republic of Moldova is a party. [...]
Wherever inconsistencies appear between human rights conventions

${ }^{17}$ See Fartunova, "Report on Bulgaria", in MARTINICO and Pollicino (eds.), cit. supra note 11, p. 101 ff., p. 113. ff.

${ }^{18}$ See Raducu, "Report on Romania", in Martinico and Pollicino (eds.), ibid., p. 369 
and treaties signed by the Republic of Moldova and its own national laws, international regulations shall prevail".

Moreover, Article 8 of the Constitution provides that "The Republic of Moldova is obliged to respect $[\ldots]$ the treaties to which it is a party $[\ldots]$ ". ${ }^{19}$

Anglo-Saxon and Scandinavian countries (the ECHR was incorporated into Swedish and Norwegian law through ordinary statutes: the Swedish Act on the ECHR of 1995 and the Act on Strengthening of the Status of Human Rights in Norwegian Law of 1999), ${ }^{20}$ but also Italy ${ }^{21}$ and Germany, ${ }^{22}$ have traditionally supported a dualistic approach, according to which international law and domestic law are two separate and distinct legal orders.

The United Kingdom and Ireland, for example, have respectively incorporated the Convention through the Human Rights Act of 1998 (entered into force in 2000) and the European Convention on Human Rights Act of $2003 .{ }^{23}$ In both countries, the reception of the European Convention made it "an immediate source of rights against national authorities and, in case of violation, a source of remedies before national courts". ${ }^{24}$ After incorporation, the ECHR rules are judicially enforceable

${ }^{19}$ See also Law No. 595-XIV of 29 September 1999 concerning the International Treaties of the Republic of Moldova. The relevant provisions of this law read as follow: "International treaties shall be complied with in good faith, in accordance with the principle pacta sunt servanda. The Republic of Moldova cannot invoke the provisions of its internal legislation as a justification for non-compliance with an international treaty to which it is a party" (Section 19 Compliance with international treaties); "The provisions of the international treaties which, according to their wording, are susceptible to be applicable without there being need for enactment of special legislative acts, shall have an enforceable character and shall be directly applied in the Moldovan law system. For the realisation of other provisions of the treaties, special normative acts shall be adopted" (Section 20 The application of international treaties).

${ }^{20}$ See LEBECK, "Report on Scandinavian Countries", in MARTINICO and Pollicino (eds.), cit. supra note 11, p. 389 ff., p. 393 ff.; WIKLUND, "The Reception Process in Sweden and Norway", in KelleR and STONE SweET (eds.), cit. supra note 3, p. 165 ff., p. $182 \mathrm{ff}$. 1.2 .

${ }^{21}$ Concerning the status and the effects of the ECHR on Italian legal order, see infra section

22 BVerfGE 111, 307 (BVerfG, Görgülü, 2 BvR 1481/04, Order of 14 October 2004), para. 34. According to the Federal Constitutional Court, the "Basic Law is clearly based on the classic idea that the relationship of public international law and domestic law is a relationship between two different legal spheres and that the nature of this relationship can be determined from the viewpoint of domestic law only by domestic law itself".

${ }^{23}$ See SAPIENZA, "L'incorporation' della Convenzione europea dei diritti umani nell'ordinamento britannico attraverso lo Human Rights Act del 1998", in CALIGIURI, CATALDI and NAPOLETANO (eds.), cit. supra note 12, p. 609 ff.; ID., "Convenzione europea dei diritti umani e Human Rights Act 1998: in margine all'obbligo delle corti inglesi to take into account la giurisprudenza della Corte di Strasburgo", DUDI, 2008, p. 253 ff.; KILKELLY (ed.), ECHR and Irish Law, 2nd ed., Bristol, 2004.

${ }^{24}$ See BESSON, "The Reception Process in Ireland and the United Kingdom", in KeLLER and StONE SweEt (eds.), cit. supra note 3, p. 31 ff., at p. 32. See also BlACK-BRANCH, "Parliamentary Supremacy or Political Expediency?: The Constitutional Position of the Human Rights Act un- 
by national courts and directly applicable within the British and Irish legal systems by courts and other public authorities. ${ }^{25}$

In particular in the United Kingdom, Section 3(1) of the Human Rights Act requires primary and subordinate legislation to be interpreted, taking into account the decisions of the Strasbourg Court (Section 2), in a way which is "as far as possible" compatible with the Convention rights. From paragraphs 2(b) and 2(c) of Section 3 , one can infer a contrario that courts can declare subordinate legislation invalid if it cannot be interpreted consistently with the ECHR, unless primary legislation prevents removal of the incompatibility. In the 2008, in In re $P$ case, ${ }^{26}$ the House of Lords made reference to Section 6(1) of the Human Rights Act, thereby preventing authorities from acting in violation of a right protected by the ECHR. In fact, the House of Lords held that if a piece of legislation cannot be interpreted consistently with the ECHR, it must be disapplied by domestic courts. ${ }^{27}$ On the other hand, in any proceeding in which a court determines that a provision of primary legislation is not compatible with a Convention right, it can declare this inconsistency (Section 4(2)). However, according to the doctrine of Parliamentary supremacy that forbids the judicial review of statutes, those provisions cannot be disapplied or declared invalid. As provided by Section 4(6), a "declaration of incompatibility", indeed, "does not affect the validity, continuing operation or enforcement" of the provision of domestic legislation, nor does it bind the parties to the proceedings in which it is made. Although the Parliament is not bound by the declaration of incompatibility, Section 10 establishes a special fast-track procedure to make those amendments to the legislation deemed necessary to remove the incompatibility with the ECHR. Finally, Section 6 makes it unlawful for a public authority "to act in a way which is incompatible with a Convention right", unless obliged to do so by primary legislation. The Human Rights Act has generated much literature and some criticisms, but it has "proven reasonably effective in the UK. In fact, it has allowed judicial review of primary legislation without overriding the supremacy of Parliament. [...] However, within the UK, the effect of the Human Rights Act has frequently been described as constitutional", ${ }^{28}$ considering the "political pressure" on Parliament to amend the law resulting from a declaration of incompatibility issued by a court, as well as the supra-legislative rank of the ECHR rights in British law that binds

der British Law", Statute Law Review, 2002, p. 59 ff.; ELLIOT, "Parliamentary Sovereignty and the New Constitutional Order: Legislative Freedom, Political Reality and Convention", Legal Studies, 2002, p. $340 \mathrm{ff}$.

${ }^{25}$ See BESSON, cit. supra note 24, pp. 42 and 46.

${ }^{26}$ See House of Lords, In re P and others (AP) (Appellants) (Northern Ireland) [2008] UKHL 38.

27 See ANDENAS and BJORge, "Giudici nazionali e interpretazione evolutiva della Convenzione europea dei diritti umani. La prospettiva inglese, francese e tedesca”, DUDI, 2010, p. 471 ff., at p. 476.

${ }^{28}$ See MURPhy, "Report on the UK and Ireland", in MARTINICO and POLLICINO (eds.), cit. supra note 11, p. 479 ff., p. 491. 
courts to interpret domestic legislation in conformity with the Convention or to declare its incompatibility with the Convention. ${ }^{29}$

In the German legal system, according to Article 59(2) of the Basic Law (Grundgesetz), the ECHR has been incorporated by a formal statute (Act on the Convention for the Protection of Human Rights and Fundamental Freedoms of 7 August 1952). Consequently, the Convention enjoys the status and the rank of a federal statute, ${ }^{30}$ and it does not automatically have priority over other federal law. In its Decision of 14 October 2004, the Federal Constitutional Court (Bundesverfassungsgericht - BVerfG) stated that the guarantees provided by the ECHR, due to its status in the hierarchy of norms, "are not a direct constitutional standard of review in the German legal system. A complainant can therefore not directly challenge the violation of a human right contained in the ECHR by a constitutional complaint before the Federal Constitutional Court". ${ }^{31}$ However, the Court has held that the European Convention must be taken into account when interpreting domestic law, including fundamental rights and constitutional guarantees. The ECHR can, indeed,

"influence the interpretation of the fundamental rights and constitutional principles of the Basic Law. The text of the Convention and the case-law of the European Court of Human Rights serve, on the level of constitutional law, as guides to interpretation in determining the content and scope of fundamental rights and constitutional principles of the Basic Law, provided that this does not lead to a restriction or reduction of protection of the individual's fundamental rights under the Basic Law". ${ }^{2}$

Therefore, German authorities and national courts are obliged, under the aforementioned conditions, to take into account the ECHR as interpreted by the ECtHR in their decisions. As a consequence, even if the ECHR does not automatically have priority over other federal law, German authorities and national courts are under an obligation to take notice of the Convention provision as interpreted by the ECHR and apply it to the case, provided that the application does not violate constitutional law. ${ }^{33}$ Accordingly, as pointed out by some scholars, the ECHR has "a quasi-con-

${ }^{29}$ See BESSON, cit. supra note 24, p. 50.

${ }^{30}$ BVerfGE 111,307 , cit. supra note 22, para. 62. See LAMBERT ABDELGAWAD and WEBER, cit. supra note 16, p. 107 ff., p. $118 \mathrm{ff}$.

${ }^{31}$ BVerfGE 111, 307, cit. supra note 22, para. 32. See HARTwIG, "Much Ado About Human Rights: The Federal Constitutional Court Confronts the European Court of Human Rights", German Law Journal, 2005, p. 869 ff.; BELJIN, "Bundesverfassungsgericht on the Status of the European Convention on Human Rights and ECHR Decisions in the German Legal Order. Decision of 14 October 2004", ECLR, 2005, p. 553 ff.

${ }^{32}$ BVerfGE 111, 307, cit. supra note 22, para. 32.

${ }^{33} \mathrm{Ibid}$., paras. 46 and 62-64. 
stitutional influence for the purpose of the application of most of the Basic Law's fundamental rights" ${ }^{\prime 4}$ that, as recently maintained by the Federal Constitutional Court in its Decision of 4 May $2011^{35}$, are to be interpreted in a manner that is open to international law. According to the Court ${ }^{36}$, an interpretation "open to international law" does not require the fundamental rights and rule-of-law principles enshrined in the Basic Law to be "schematically aligned" with those of the ECHR but requires "its valuations to be taken on to the extent that this is methodically justifiable and compatible with the Basic Law's standards". Furthermore, the decisions of the ECtHR, which contain new aspects for the interpretation of the Basic Law, "are equivalent to legally relevant changes, which may lead to the final and binding effect of a Federal Constitutional Court decision being transcended".

The constitutions of some Contracting States reserve a special status to international human rights treaties (see, respectively, Article 10 of the Spanish Constitution and Article 16 of the Portuguese Constitution). More specifically, the relevant provisions of the Spanish Constitution read as follows: "Provisions relating to the fundamental rights and the freedoms recognised by the Constitution shall be construed in accordance with $[\ldots]$ international treaties and agreements on human rights that have been ratified by Spain" (Article 10(2)); "Once officially published in Spain, international treaties that have been validly concluded shall be part of the domestic legal order" (Article 96(1)). The Spanish Constitution confers a "supra-legislative" rank to the ECHR, that is placed above domestic legislation and below the Constitution. ${ }^{37}$ Hence, domestic legislation may not, even if enacted subsequently, modify or derogate from an international treaty. Moreover, the ECHR has an "infra-constitutional" rank; this status derives from Article 95(1) of the Constitution, which states that if an international treaty contains provisions incompatible with the Constitution, its ratification requires a previous amendment of the Constitution itself. Finally, Article 10(2) requires that constitutional fundamental rights must be interpreted consistently with international human rights treaties, thus with the ECHR. The Spanish Constitutional Court (Tribunal Constitucional) has repeatedly maintained that ECHR can integrate the content of constitutional rights, having a special relevance for the interpretation of those rights. However, the ECHR is not an autonomous parameter under which domestic legislation can be reviewed, having a special relevance for the interpretation of constitutional rights. ${ }^{38}$ As far as

${ }^{34}$ See Cede, "Report on Austria and Germany", in Martinico and Pollicino (eds.), cit. supra note 11, p. 55 ff., p. 62 ff.

${ }^{35}$ BVerfG, 2 BvR 2365/09; 2 BvR 740/10; 2 BvR 2333/08; 2 BvR 1152/10; 2 BvR 571/10 of 4 May 2011.

${ }^{36}$ See English Press release No. 31 of 4 May 2011 is available at: <http://www.bundesverfassungsgericht.de/en/press/bvg11-031en.html>.

${ }^{37}$ See Candela Soriano, "The Reception Process in Spain and Italy", in Keller and STONE SWEET (eds.), cit. supra note 3, p. 393 ff., p. $403 \mathrm{ff}$.

${ }^{38}$ See TorRes PÉRez, "Report on Spain", in MARTINICO and Pollicino (eds.), cit. supra note 11, p. 457 ff., p. $461 \mathrm{ff}$. 
ordinary courts are concerned, since international treaties cannot be amended or derogated from by domestic legislation, the Tribunal Constitucional has ruled out that national courts may set aside legislation clashing with the ECHR, or, in case of doubt, they may raise a question of constitutionality asking the Constitutional Court to review the compatibility of domestic legislation with a fundamental right protected by the ECHR and the Constitution. ${ }^{39}$

Only few Contracting Parties have acknowledged a constitutional status of the European Convention. For instance, in Austria the ECHR has been incorporated into the domestic constitutional order and is directly applicable - even if Austria has always denied any direct applicability of international human rights treaties. ${ }^{40}$ This, therefore, determines that: a) the ECHR is a directly binding standard under which ordinary laws may be reviewed by the Constitutional Court; $b$ ) the ECHR grants individual rights that are directly actionable before all national courts and authorities, which are obliged to interpret ordinary law consistently with the Convention.

However, it must be noted that, lacking a formal incorporation, more specifically made by a formal act of the Parliament, the practice has recorded an increasing recourse to the "indirect incorporation" of the Convention, that is to say the incorporation made by national courts interpreting domestic legislation in the sense the most consistent with international obligations lying upon States, through the well known criterion of the so called "consistent interpretation". As mentioned above, the ECHR is seen as interpretative tool in relation to national constitutional provisions in the field of human rights. The fundamental principle is, therefore, that the interpretation of national rights be inspired by the evolution of the ECHR. As a consequence, the different national legal orders and the ECHR system influence one another and mutually stimulate. ${ }^{41}$ In fact, regardless of the formal position set out by the different constitutional texts and regardless of the monistic or dualistic approach, ${ }^{42}$ some scholars have recently underlined that there

\footnotetext{
${ }^{39}$ Ibid., pp. 465 and 473.

${ }^{40}$ See THURNHER, "The Reception Process in the Austria and Switzerland", in Keller and STONE SWEET (eds.), cit. supra note 3, p. 311 ff., p. $325 \mathrm{ff}$.

${ }^{41}$ See ANDENAS and BJORGE, cit. supra note 27, p. $485 \mathrm{ff}$.

${ }^{42}$ See Keller and Stone Sweet, "Assessing the Impact of the ECHR on National Legal Systems", in Keller and STONE SweET (eds.), cit. supra note 3, p. 677 ff., p. 685 ff.: "[T] here is no necessary causal linkage between ex ante monism or dualism, on one hand, and the reception of the ECHR on the other. Put differently, the manner in which the ECHR is incorporated is an outcome of the reception process which will, in turn, impinge on reception ex post. The assumption that dualistic States have, a priori, an unfriendly attitude towards international law, and will, therefore, generate a relatively poorer rights record, is untenable. [...] Dualistic countries tend to incorporate through statute, whereas monist States tend to do so through judicial decisions. Clearly, a monistic constitutional structure can provide the judiciary with more leeway in the reception process $[\ldots]$ helping courts overcome certain obstacles when they are motivated to do so. Finally, in dualistic countries where a powerful Constitutional or Supreme Court defends national human rights, we observe reticence among judges to base their rulings on the Convention as an
} 
is a "progressive rapprochement between the European legal orders with regard to the 'position' of the ECHR in the domestic legal order, which has been promoted by national legislators, by Constitutional or the Supreme Courts, and sometimes the ordinary judges". ${ }^{43}$

In conclusion, the legal framework governing the application and the effects of the ECHR in the domestic legal orders is so variegated that, according to some scholars, it is necessary to develop

"a new, more comprehensive realistic theory. [...] [This new theory] should not only accept that the reality is more complex and that, just as there are various shades of black and white, so there are various shades of monism and dualism, [...] [but should be able to] tell us: whether domestic courts apply the Convention by relying only on the wording of the Convention or (as they should) also on the case law of the European Court; or whether they apply only domestic law, but so as to harmonize it with the Convention and the Court's case-law; or whether they give priority only to earlier or also to subsequent statutory and/or constitutional law". ${ }^{44}$

\subsection{Focus on the Status and Effects of the ECHR in the Italian Legal System}

The Italian Constitution recognizes a particular status to international law, distinguishing between customary law and treaty law (Articles 10(1) and 117(1) of the Italian Constitution). After the constitutional reform of 2001, which introduced a new Article 117(1) according to which "[l] egislative powers shall be vested in the State and the Regions in compliance with the Constitution and with the constraints deriving from EU-legislation and international obligations", the Italian Constitutional Court (Corte Costituzionale) has had different occasions to rule on the issue of the relationship between the ECHR and the Italian legal system, in particular focusing on the distinction between those competences that are a prerogative of the Court itself and those that can be exercised by any other domestic court while interpreting and applying the Convention.

independent source of rights. [...] Paradoxically, perhaps, a pre-existing human rights judicial tradition in a particular country can sometimes hamper reception of the Convention or, at least, the jurisprudence of the ECtHR".

${ }^{43}$ See MARTINICO, "National Judges and Supranational Laws: Goals and Structure of the Research", in MARTINICO and POLLICINO (eds.), cit. supra note 11, p. 7 ff., p. 13.

${ }^{44}$ See WILDHABER, "The European Convention on Human Rights and International Law", ICLQ, 2007, p. 217 ff., p. 219. 


\subsubsection{Status of the ECHR}

Concerning the status of the ECHR, the Corte Costituzionale maintains that Article 117(1) of the Italian Constitution has filled the gap hitherto existing in the rules that guarantee compliance with international treaty obligations at a constitutional level, establishing, as a consequence, that a conflict between a rule of domestic law and a rule of international treaty law, in particular of the ECHR, amounts to a violation of Article 117(1). ${ }^{45}$ Moreover, while excluding that Article 117(1) confers constitutional rank to international treaty law incorporated into the Italian legal system - the ECHR was ratified and implemented by Italy by Law No. 848 of 4 August 1955, having therefore formally the rank of ordinary law -, the Court has specified that the expression "international obligations" mentioned in it refers to international treaty rules different from those referred to by the provisions of Articles 10 and 11 of the Constitution. Therefore, Article 117(1), with its inherent mechanism of "mobile reference" (rinvio mobile), mandates the verification of the constitutionality of any ordinary law in light of any relevant rule of international treaty law, thus the ECHR itself.

In particular, in its Decisions Nos. 348 and 349 of $2007,{ }^{46}$ the Corte Costituzionale held, with reference to Article 117(1), that the provisions of the ECHR must be considered as "intermediate rules" (norme interposte) - i.e. in the domestic hierarchy of sources of law, ECHR rules are midway between the Constitution and ordinary legislation and integrate a parameter of constitutionality for reviewing national legislation (Decision No. 349 of 2007, para. 6.2) - and that their specificity lies in the fact that they are subject to the interpretation of the Strasbourg Court, to which Contracting Parties are obliged to conform (Decision No. 349 of 2007, para. 5). Even if the Italian Constitution does not expressly refer to the ECHR and even if

${ }^{45}$ Before the constitutional reform of 2001, the Corte di Cassazione, in its Decision of 10 July 1993 No. 2194, issued in the Medrano case, recognized to the ECHR rules "a particular force of resistance in respect to ordinary subsequent laws". Moreover, the Corte Costituzionale (19 January 1993, No. 10) stated that the rules of international treaty law introduced in the domestic legal system "derive from an atypical competence of the State, as such insusceptible of being abrogated or modified by means of ordinary law".

${ }^{46}$ See Corte Costituzionale, 24 October 2007, Nos. 348 (R.A. v. Comune di Torre Annunziata; Comune di Montello v. A.C.; M.T.G. v. Comune di Ceprano) and 349 (E.P. et al. v. Comune di Avellino et al.; A. G. et al. v. Comune di Leonforte et al.), IYIL, Vol. XVII, 2007, p. 292 ff. (commentary by CATALDI). On these decisions see also the contributions by BARTOLE, CONDORELLI, Caretti, Cataldi, and Padelletti, in DUDI, 2008, p. 291 ff., and by Gaja, Cannizzaro, PADElletti, and SACCUCCI, in RDI, 2008, p. 136 ff.; CONFORTI, "La Corte costituzionale e gli obblighi internazionali dello stato in tema di espropriazione", Giur. It., 2008, p. 569 ff.; VILLANI, "Sul valore della Convenzione europea dei diritti dell'uomo nell'ordinamento italiano", Studi sull'integrazione europea, 2008, p. 7 ff.; TESAURO, "Costituzione e norme esterne", DUE, 2009, p. 195 ff.; PEDRAZZI, "La CEDU nell'ordinamento italiano", in CALIGIURI, CATALDI and NAPOLETANO (eds.), cit. supra note 12, p. 595 ff.; NAPOLETANO, "Rango ed efficacia delle norme della CEDU nella recente giurisprudenza della Corte costituzionale", DUDI, 2010, p. $194 \mathrm{ff}$. 
the Convention rules do not automatically prevail over conflicting domestic rules in the sense the conflicts between the ECHR and domestic laws cannot be directly resolved by ordinary courts, but must be referred to the Corte Costituzionale -, the ECHR binds the legislator considering that its rules are an indirect parameter for constitutional review of domestic laws. As a consequence, any domestic law in conflict with the ECHR as interpreted by the ECtHR indirectly violates the Italian Constitution and can be repealed by the Corte Costituzionale (this approach has been confirmed by the Corte Costituzionale in many subsequent decisions: No. 39 of 2008; Nos. 311 and 317 of 2009; Nos. 138, 187 and 196 of 2010; Nos. 1, 80 and 113 of 2011).

\subsubsection{Role of Domestic Courts}

As far as the role of domestic courts is concerned, the Corte Costituzionale states that, in case of conflict between a domestic law and the ECHR, the "common" judge shall construe the former consistently with the Convention "to the extent that this is allowed by comparing the text of the two provisions and using all the standard tools of legal hermeneutics". ${ }^{47}$ If the conflict between the two rules cannot be solved by way of interpretation, the Corte Costituzionale has held that "the common judge [...] must raise a plea of unconstitutionally [...] with reference to the parameter of Article 117(1) of the Constitution and, if it is a treaty rule coinciding with a generally recognized rule of international law, to the parameter of Article 10(1) of the Constitution as well"' (Decision No. 311 of 2009, para. 6).

As a consequence, domestic courts do not have the power to set aside domestic laws in contrast with the ECHR, since the alleged incompatibility between these two sources of legislation amounts to a question of constitutionality falling under the exclusive jurisdiction of the Corte Costituzionale (Decisions Nos. 348, para. 3.3, and 349, para. 6.1, of 2007). Moreover, in the Decision No. 39 of 2008, ${ }^{48}$ the Corte Costituzionale indirectly confirmed that also with reference to pre-existing rules it will be necessary to wait for its decision in order to repeal the provision in contrast with the ECHR. Any antinomy between domestic and international law must, in any case, be resolved by the Court, even when it can be maintained that the ECHR provisions, within the meaning arising from a constant case law of the Strasburg Court, can be immediately applied by the national court given their precise, unconditional and complete character.

${ }^{47}$ See Corte Costituzionale, 26 November 2009, No. 311, para. 6. A reference to the criterion of consistent interpretation in order to guarantee the application of domestic law compatible with international treaty law is contained also in Decision No. 349 of 2007, cit. supra note 46, para. 6.2, and Decision No. 239 of 24 July 2009, para. 3.

${ }^{48}$ See Corte Costituzionale, B.R. v. Provincia di Reggio Emilia et al., 27 February 2008, No. 39, IYIL, Vol. XVIII, 2008, p. 360 ff. (commentary by NAPOLETANO). 
The Corte Costituzionale does not deal with the question of unconstitutionality in light of the principle of the temporal succession of laws ${ }^{49}$ It must be noted that the ECHR shall apply, at least with reference to its self-executing rules, therefore determining the repealing of pre-existing domestic laws in contrast with it. Regardless of any other argument on the supremacy of international obligations even on subsequent laws, one can maintain that if a domestic court identifies a conflict between the ECHR and a pre-existing national law that cannot be solved by way of interpretation, it will simply disapply the latter as it violates the European Convention, whose provisions must be reconstructed taking into account the ECtHR case law.

The Corte Costituzionale, however, does not seem to share this opinion, rather reaffirming and extending the effects of Article 117(1) of the Italian Constitution on the existing domestic law prior to the entry into force of the ECHR. In the Court's view, Article 117(1), on one hand, attributes a particular "force of resistance" to domestic laws implementing international treaties, such as the ECHR, in case of conflict with ordinary legislation. On the other hand, it brings international treaties under the jurisdiction of the Corte Costituzionale, since "eventual conflicts will not generate problems of the temporal succession of laws or assessments of the respective hierarchical arrangement of the provisions in contrast, but questions of constitutionality" (Decision No. 348 of 2007, para. 4.3).

It is a reason of concern that the Court does not allow domestic courts to set aside, while interpreting a rule, pre-existing provisions of national law incompatible with specific obligations of international law. ${ }^{50}$ It would be desirable that the Court change this position. Indeed, the issue not only relates to cases of conflict between a national provision entered into force before the ECHR and the Convention itself, but also to all other international treaties of "great significance" ratified more recently by Italy, including the new Protocols to the Convention.

\footnotetext{
${ }^{49}$ See, on this point, MASTROIANNI, "Anche le leggi precedenti la Convenzione europea dei diritti dell'uomo debbono essere rimosse dalla Corte costituzionale?", RDI, 2008, p. $456 \mathrm{ff}$.

${ }^{50}$ In its referral order that led the Corte Costituzionale to pass the Decision No. 39, the Tribunale Amministrativo Regionale (Regional Administrative Tribunal) of Emilia Romagna held that, although the ECHR is binding on Italy, the enforcement of human rights under the Convention concerns national legislation and the Convention rules are not directly applicable in the domestic legal system. The TAR implicitly denied any possibility of automatic abrogation or non-application by a court of domestic laws in conflict with the ECHR, as the power of repealing a law in contrast with international obligations is an exclusive competence of the national and regional legislator, as well as of the Corte Costituzionale, when ruling on questions of constitutionality, especially with reference to Article 117(1) of the Constitution. It is a matter of concern that the Corte Costituzionale did not censure the TAR's anachronistic point of view, even when the latter denied the direct applicability of the ECHR and stated that the European Convention creates only inter-governmental obligations that do not confer any power to national courts to set aside domestic laws, also in the case they have been superseded by subsequent international treaty provisions. See CONFORTI, "Atteggiamenti preoccupanti della giurisprudenza italiana sui rapporti fra diritto interno e trattati internazionali", DUDI, 2008, p. $581 \mathrm{ff}$.
} 
Another interesting aspect that must be pointed out concerns the competence of domestic courts to raise a question of constitutionality with reference to Article 10 of the Constitution, in the case the ECHR rule coincides with a generally recognized rule of international law. According to some scholars, the Court wants to reaffirm explicitly the automatic incorporation into the Italian legal system of the rules of the European Convention that, though codified in an international treaty, reproduce international customary law. ${ }^{51}$

Moreover, another element can be taken into consideration in order to understand why the Court specifies a twofold parameter, Articles 117 and 10 of the Constitution, for challenging the constitutionality of a domestic law. While affirming that the domestic court is "barred from disputing the interpretation of the ECHR given by the Strasbourg Court", the Corte Costituzionale reserves the competence to verify whether "the ECHR rule, as construed by the European Court, [...] is in conflict with the other relevant rules of the [...] [Italian] Constitution". ${ }^{52}$ In this case, the review of the Court cannot be "limited to the possible infringement of the principles and fundamental rights of the Constitution, but must be extended to conflicts between the "intermediate rules' and the Constitution". ${ }^{33}$ So, the Constitutional Court maintains that ECHR provisions, as interpreted by the ECtHR, can be applied only if they are consistent with the Constitution. This is an important specification, considering that in the case law prior to the 2001 constitutional reform the Court had stated that "in the absence of a specific constitutional basis", when the rules of international treaty law are implemented into the domestic legal system by an ordinary law, "the constitutional limit operates in its entirety, as it happens with respect to any other [domestic] law". ${ }^{54}$ As mentioned above, the European Convention was, in fact, ratified and implemented by Italy by an ordinary law and the Corte Costituzionale has excluded, as a general rule, that the ECHR falls within the field of application of Articles 10 and 11 of the Constitution (Decisions Nos. 348 and 349 of 2007).

Therefore, in case of conflict with the Italian Constitution, the effectiveness of the mechanism of "mobile reference" to international law as provided for in Article 117(1) would be excluded and, as a consequence, the ECHR rule could not account for a parameter of constitutionality for reviewing domestic laws (Decision No. 311 of 2009, para. 6). On the contrary, if a ECHR rule coincides with a rule of international customary law, the reference to Article 10(1) of the Constitution narrows the competence of the Constitutional Court only to verify whether that ECHR rule is in conflict with the "fundamental principles of the constitutional legal order" and the "inalienable human rights", and not with all the relevant rules of the Constitution.

${ }^{51}$ See TeSAURO, cit. supra note 46, p. 214.

${ }^{52}$ See Corte Costituzionale, No. 311 of 2009, cit. supra note 47, para. 6.

${ }^{53}$ See Corte Costituzionale, No. 348 of 2007, cit. supra note 46, para. 4.7, and No. 349 of 2007, cit. supra note 46, para. 6.2 .

${ }^{54}$ See Corte Costituzionale, 23 March 2001, No. 73, para. 3.1. 
This case law leads potentially to a two-tier constitutional status of the human rights protected by the ECHR.

One can assume that the Court takes into account the aforementioned distinction when it contemplates, as an exceptional hypothesis, the possibility of challenging the constitutionality of the Italian law implementing the European Convention, and declaring the unconstitutionality of the part of this law which incorporates the ECHR rules in conflict with the Constitution. The same distinction is also important when considering the consequences deriving from another aspect pointed out by the Court. The Corte Costituzionale held that, in order to increase the standard of protection of any human right in the domestic legal system, the application of the ECHR, as construed by the ECtHR, needs to be balanced with "the other interests guaranteed by the Constitution, i.e. the other constitutional rules protecting fundamental rights that could be affected by the extension" of the protection of the right concerned (Decision No. 317 of 2009, para. 7)..$^{55}$ In conclusion, whereas the reference parameter is Article 10(1) Constitution, the competence of the Corte Costituzionale should be confined to the verification of the compatibility of the ECHR rule with respect to the "fundamental principles of the constitutional legal order" (the so called "supreme values of the Constitution"); as such, no balance test between the standard of protection deriving from the ECHR and other interests guaranteed by the Constitution should be carried out.

According to the Constitutional Court case law, "the common judge [...] cannot apply a ECHR rule (at present, differently from a rule of EC [now EU] law that has direct effect) instead of the conflicting domestic one, and cannot even less apply a rule of domestic law that he deems in conflict with the ECHR, and therefore with the Constitution" (see Decision No. 311 of 2009, para. 6). In other words, the Convention does not produce effects in the domestic legal order capable of establishing the jurisdiction of national courts to apply directly its provisions in disputes pending before them, ${ }^{56}$ and to avoid at the same time the application of the relevant

\footnotetext{
${ }^{55}$ See also Corte Costituzionale, 4 December 2009, No. 317, IYIL, Vol. XIX, 2009, p. 437 ff. (commentary by PALOMBINO).

${ }^{56}$ From the incorporation of the ECHR till the 1980s, Italian courts have given a number of decisions concerning the status of the Convention in Italian domestic legal order. These decisions have never recognized that the ECHR has a constitutional status nor that the Convention ranks midway between the Constitution and ordinary laws, that is to say whether it prevails even over laws enacted after the Convention was ratified by Italy. In 1988, in the Polo Castro case (8 May 1989, No. 15, IYIL, Vol. VIII, 1988-1992, p. 126 ff.) the Corte di Cassazione held that "the provisions of the ECHR, with the only exception of those worded in a very imprecise and generic way as to sustain an individual claim, are immediately applicable within the domestic legal order", recognizing the direct applicability of the ECHR rules that contained "the model of a national act complete in its essential elements". In 2002, in the Muscas case (19 July 2002, No. 10542, IYIL, Vol. XIII, 2003, p. 235 ff., commentary by BRUNO) the Corte di Cassazione maintained that any direct application of the provisions of the Convention "is the responsibility of the national judge who, if perceives any conflict with the national law, must give precedence to the conventional rule provided with immediate binding effect in respect of the concrete case, even if this means
} 
conflicting domestic law. Moreover, the Court has held the thesis that, differently from what happens with a rule of EU law that has "direct effect", the domestic court is barred from applying directly the ECHR rules in place of rules of domestic law inconsistent with the European Convention. In Decisions Nos. 348 and 349 of 2007 (and also in its subsequent decisions) the Court has never missed the opportunity to reaffirm the difference between the EU law rules having direct effect and the rules of the European Convention whose "direct effect" is denied. From this perspective, considering that Article 117(1) of the Constitution (that provides the obligation of fulfilling international obligations) is not sufficient to recognize to the ECHR the same status as the EU law, ${ }^{57}$ it is difficult to envisage what could instigate a shift towards the recognition of "direct effect" to the ECHR rules.

It is hard to share the opinion of the Court, insofar as it leads to apply widely the notion of direct effect in order to rule out the direct applicability of the ECHR provisions. Indeed, the direct applicability and the direct effect of an international treaty rule cannot be limited to some treaties, such as the EU Treaties, and ruled out as to others, such as the ECHR, nor can it be excluded for treaties in general regardless of the specificity of the provisions therein. The circumstance that an international provision does not require any implementing legislation within Member States or that an international obligation imposed upon States by a treaty is directly enforceable by individuals before their domestic courts is a question that should be considered on a case-by-case basis, taking into account the clear, precise and unconditional character of the international rule, as well as the object and purpose of the treaty.

A possible solution to the question of the effects of the European Convention in the Italian system could be found by setting aside the comparison - incisively outlined by the Corte Costituzionale in the Decisions Nos. 348 and 349 of 2007 between the ECHR system and the "supranational" EU system. In particular, this would require to abandon the expression "direct effect" and to use the concept of self-execution when analyzing and determining the effects of the rules deriving from treaties different from those establishing the EU. It is well-known that the EU legal system is different from any other legal system based on an international treaty. As a consequence, a comparison between the EU and the ECHR systems (or a system deriving from any other international treaty) would inevitably lead to deny the "direct effect" of the rules deriving from the latter. As pointed out by some scholars,

"[i]n principle, substantive provisions of the ECHR are self-executing. Rather, by saying that the ECHR does not have direct effect, the

the non-application of the national rule". The same conclusion was confirmed by the Corte di Cassazione in the case Centurione Scotto v. Presidenza del Consiglio dei Ministri (23 December 2005, No. 28507, IYIL, Vol. XVI, 2006, p. 314 ff., commentary by BRUNO).

${ }^{57}$ See CATALDI, cit. supra note 46, p. 294. 
Court seems to rule out a particular effect, specifically the setting aside of inconsistent national law. This is precisely the meaning of the term 'direct effect' within the conceptual framework of EU law [...] Thus, $[\ldots]$ the Constitutional Court seems to allude (inadvertently) to the very thin conceptual line which separates the notion of direct effect from that of self-execution". ${ }^{58}$

Considering the present constitutional structure and without any particular hermeneutic effort, it would be easier to find a solution to the question of the impact of the ECHR on the Italian legal system, if the Court started to consider the applicability of the European Convention provisions in light of their complete character and their immediately preceptive nature. In its Decision No. 311 of 2009, the Corte Costituzionale partially went in this direction by stating: "the domestic judge, as the common judge of the Convention, has the duty to apply the relevant rules, as interpreted by the Strasburg Court". Therefore, one can infer that the competence of the ordinary courts to apply the ECHR is limited only by the existence of a conflict with a domestic law provision and by the impossibility to solve this conflict by way of interpretation. Accordingly, the domestic judge should be seen as fully competent to apply the ECHR in all cases when he is not bound to raise the plea of unconstitutionality before the Corte Costituzionale. If this interpretation is correct, the recent case law of the Constitutional Court shows an opening to the direct application of the ECHR by the domestic courts and consequently to the possibility that an individual can rely directly on the ECHR rights before them, ${ }^{59}$ at least in all cases where the application of the ECHR does not entail the non-application of a domestic rule. Domestic courts can apply directly the ECHR rules, as construed by the European Court, in order to extend the applicability of a right already protected at national level to more specific cases $^{60}$ or when there is the need for filling a legal loophole in the domestic system. ${ }^{61}$ This conclusion is not hindered by the need to reach the "necessary balance" between the conventional and the domestic protection of fundamental rights, because the Corte Costituzionale itself entrusts with this task also the lower courts (Decision No. 317 of 2009, para. 7).

${ }^{58}$ See CANNIZZARO, "The Effect of the ECHR on the Italian Legal Order: Direct Effect and Supremacy", IYIL, Vol. XIX, 2009, p. 173 ff., p. 177. On this point, see NOLLKAEMPER, "The Effect of the ECHR and the Judgments of the ECtHR on National Law - Comments on the Paper of Enzo Cannizzaro", ibid., p. 89 ff., who argues "that there exists quite and essential distinction between direct effect and supremacy [...] The combination of direct effect and supremacy is unique in European law, and is there where the real power of direct effect lies. But direct effect certainly is not limited to this, and judicial practice shows many examples where courts could give direct effect without a question of supremacy arising" (p. 193).

${ }^{59}$ See TeSAuro, cit. supra note 46, p. $217 \mathrm{ff}$.

${ }^{60}$ See, for instance, Corte di Cassazione, Drassich, 11 December 2008, No. 45807.

${ }^{61}$ See, for instance, Corte di Cassazione, Dorigo, 25 January 2007, No. 2800, IYIL, Vol. XVI, 2006, p. 317 ff. (commentary by PALOMBINO). 
However, it must be noted that, even welcoming the specification made by the Court, some doubts concerning the definition of the precise status of the European Convention within the Italian legal system still exist and do concern the impact of the ECHR rules on the Italian law. It cannot be forgotten, in fact, that the ECHR accounts for a binding parameter of international law, as per Article 117(1) of the Constitution, as well as for a system of protection of fundamental rights already provided by the Constitution. As such, the ECHR not only "reaffirms the protection guaranteed by constitutional provisions, but [...] [contributes] to determining its perceptive content". ${ }^{62}$

\subsubsection{Role of the Corte Costituzionale}

Concerning the role of the Corte Costituzionale, it has the threefold duty to: a) "verify whether a conflict exists and cannot be settled at all through an acceptable interpretation, including a systematic interpretation, of the rule of domestic law in light of the ECHR rule, as construed by the Strasburg Court"; b) "verify whether the conflict is determined by a standard of protection provided by the rule of domestic law which is lower than the one guaranteed by the ECHR, as Article 53 of the European Convention itself considers expressly compatible the contrary hypothesis"; c) "in case of conflict, [...] [declare] the unconstitutionality of the rule of domestic law as inconsistent with Article 117(1) of the Constitution with reference to the relevant ECHR rule". ${ }^{63}$

Consequently, considering also the clear reference to Article 53 ECHR, it seems that the hypothesis of a challenge to the constitutionality of the Italian law implementing the European Convention is not only exceptional, but also unlikely to occur. After affirming the subsidiary character of the Convention and denying "direct effects" to the ECHR rules, it is almost unnecessary to refer to the constitutional counter-limits. In fact, when a ECHR rule, as construed by the Strasbourg Court, limits or jeopardizes fundamental rights and freedoms guaranteed by the Constitution, the Corte Costituzionale excludes "the effectiveness of the reference to international law and, therefore, the capacity of the latter to integrate the parameter set by Article 117(1) of the Constitution" ${ }^{64}$ Accordingly, in the Decision No. 317 of 2009 , the Court held that:

"With reference to a fundamental right, the compliance with international obligations can never determine a lower level of protection compared to the standard already existing in the domestic legal sys-

${ }^{62}$ See CANNIZZARO, "Gerarchia e competenza nei rapporti fra trattati e leggi interne", RDI, 1993, p. 351 ff., p. 369.

${ }^{63}$ See Corte Costituzionale, No. 311 of 2009, cit. supra note 47, para. 6.

${ }^{64}$ Ibid. 
tem but, vice versa, it can and must amount to an effective instrument to extend the protection itself. [...] Besides, Article 53 of the European Convention requires that the interpretation of the ECHR provisions cannot lead to a level of protection which is lower than the one guaranteed by domestic sources. [...] It is clear that this Court cannot accept that, through Article 117(1) of the Italian Constitution, a level of protection lower than the one established in the domestic system is guaranteed; likewise, it cannot admit that a higher level of protection, that could be introduced in the same way, is denied to an individual entitled to a fundamental right. The consequence of this reasoning is that the comparison between conventional and constitutional protection of fundamental rights must be made aiming at the maximum possible extension of guarantees, also developing the potential of the constitutional rules concerning the same rights. [...] The overall result of the integration of national guarantees must have a plus sign, in the sense that the impact of a single ECHR rule on the Italian law must generate a higher standard for the entire fundamental rights protection system" (para. 7).

In conclusion, considering the subsidiary character of the protection system established by the ECHR, both the Corte Costituzionale and the domestic courts should not be bound to apply those ECHR rules that, according to the interpretation of the Strasburg Court, determine a violation of the standard of protection guaranteed by the Italian legal system. This would be true even affirming the selfexecuting character of the rules of the European Convention, whose application would anyway be conditioned by its compliance with the Constitution. As argued by some scholars,

"the non-application by the courts of national laws that are incompatible with the ECHR (with the contextual direct application of the conventional rule as interpreted by the Strasbourg Court) can undoubtedly coexist with the Constitutional Court's review, which should be called upon in particular cases where the inconsistency between the domestic rule and the ECHR rule amounts to a 'systemic violation' of the Convention",

i.e. a persistent and reiterated violation caused by structural or general deficiencies in the national law or practice. ${ }^{65}$ The same could be true where a domestic court has no possibility to interpret national law consistently with the ECHR, but

${ }^{65}$ See CATALDI, cit. supra note 12, p. 573; ID., cit. supra note 46, p. 301. 
the domestic provision needs to be repealed by the Constitutional Court in order to abide by a final decision of the Strasbourg Court. ${ }^{66}$

\subsubsection{Status and effects of the ECHR after the Accession of the EU}

After the abovementioned decisions of the Constitutional Court, Italian administrative courts again dealt with the question of the direct applicability of the ECHR rules. The Consiglio di Stato, in its Decision of 2 March 2010, No. 1220, held that the ECHR rules have become "directly applicable" in the national legal system as a consequence of the modification of Article 6 TEU following the coming into force of the Treaty of Lisbon. Similarly, the Administrative Regional Tribunal (TAR) of Lazio, in its Decision of 18 May 2010, No. 11984, affirmed that, as the EU Treaty provides the accession of the European Union to the ECHR (Article 6 TEU), "the acknowledgement of the fundamental rights set by the ECHR as principles inherent in Union law has immediate consequences of the utmost importance, as the Convention rules become immediately effective in the national legal systems of member States, through EU law, and therefore in Italy according to Article 11 of the Constitution". ${ }^{67}$

However, looking at the decisions of the administrative courts, it is not clear the reasoning that led to the acknowledgement of the "immediate effectiveness" or the "direct applicability" of the Convention rules in the national legal system on the basis of the new wording of Article 6 TEU. In other words, it is not clear whether the administrative courts draw the direct applicability of the Convention rules from Article 6(2) TEU ("The Union shall accede to the ECHR") or Article 6(3) TEU ("Fundamental rights, as guaranteed by the ECHR and as they result from the constitutional traditions common to the Member States, shall constitute general principles of the Union's law"). Therefore, the thesis maintained by administrative courts that the ECHR direct effects in Italy can derive from UE law does not seem persuasive. On one hand, Article 6(3) TEU, reaffirming what was already provided in the previous versions of the EU Treaty, does not appear able to give direct effect to the ECHR rules into the national legal system. On the other hand, the EU accession to the Convention will not be able to guarantee, on the basis of Article 11 of the Constitution, the national courts the possibility to apply directly the ECHR rules setting aside the inconsistent national laws.

Recently, in its Decision of 15 September 2010, No. 5988, the TAR of Lombardia tackled the same questions already dealt with by the Consiglio di Stato and the TAR Lazio in the abovementioned decisions, adopting a more correct ap-

${ }^{66}$ See Corte Costituzionale, 4 April 2011, No. 113. Concerning the effects of judgments and of the case law of the ECtHR on national legal orders, see infra section 2.

${ }^{67}$ See TERRASI, "Il giudice amministrativo e l'applicabilità diretta della CEDU all'indomani dell'entrata in vigore del Trattato di Lisbona", DUDI, 2010, p. $682 \mathrm{ff}$. 
proach. Maintaining in any case that it is premature to deal with the consequences of the future accession of the EU to the ECHR with reference to the direct applicability of the Convention rules, the TAR held that:

\begin{abstract}
"By the accession to the ECHR, the Convention will take, on the contrary, the same position as international treaties in the system of the sources of EU law so that, once entered in the national legal system through the EU law, it will acquire all the characteristics typical of the EU law in terms of primacy, direct effect, possibility for the court to disapply the national law inconsistent with it (with the risk of having regime for those ECHR rights not introduced by EU law)" (para. 5.1.).
\end{abstract}

More recently, this approach was confirmed by the Corte Costituzionale in its Decision of 11 March 2011, No. 80. The Court held, indeed, firstly that new paragraphs 1 and 3 of Article 6 TEU cannot be interpreted as recognizing direct effect to the rules of the ECHR in the Italian legal system and as authorizing the domestic court to disapply national laws inconsistent with them. Secondly, any reasoning supporting the direct effect of the ECHR rules cannot actually be grounded on Article 6(2) TEU, considering that an accurate definition of the effects of this provision will depend on the conditions and modalities set out in the Agreement on the Accession of the EU to the European Convention (para. 5.3).

2. EFFECTS OF Judgments AND CASE LAW OF the ECtHR on NATIONAL LEGAL SYSTEMS

\title{
2.1. Obligations Arising from Article 46(1) ECHR as Interpreted by the ECtHR
}

The European Convention envisages that final judgments of the ECtHR shall be binding on the parties to the proceedings. In Article 46(1) ECHR the Contracting States have provided that, in all legal disputes to which they are party, they will comply with the final judgments of the ECtHR. It follows from this article that the judgments of the ECtHR have only inter partes effects. However, this provision does not specify the content of such obligation, leaving the door open to interpretation.

\subsubsection{Binding Effects of Final Judgments against Respondent States}

As is well known, every final judgment of the ECtHR has the effect of res judicata for the respondent State. However, this judgment is essentially declaratory and leaves to the State the choice of the means for complying with its obligation under 
Article 46(1) ${ }^{68}$ Indeed, the ECtHR does not possess the authority to invalidate national norms or to revise final decisions of national courts judged to be inconsistent with the European Convention; rather, "states must work backwards from the violation to understand what must be changed to remedy the violation in the specific case and to avoid what future cases might also arise". ${ }^{9}$

The obligation of the respondent State to give effect to the judgment of the ECtHR must be complied with through measures appropriate to the particular case (restitutio in integrum, if the nature of the breach allows it, or just satisfaction). ${ }^{70}$ However, if at the origin of the violation there is a legal provision or a practice, the adoption of measures of a general nature is needed in order to prevent future violations. In its recent practice, the ECtHR tends to limit the freedom of the State in selecting suitable measures, indicating which individual measures or general measures to be taken in order to give effect to its judgment. ${ }^{71}$

The binding effects of the final judgments of the ECtHR are addressed to all the bodies of the respondent State. However, a legislative measure might be required in order to remedy a structural deficiency in the national system. In case of default of legislative power, the domestic judge may find himself also assuming functions that may be defined as "legislative substitution", in cases in which the national system does not allow for review of a final judgment in a proceeding recognized by the ECtHR as being inconsistent with the European Convention. ${ }^{72}$ On specific

${ }^{68}$ ECtHR, Marckx v. Belgium, Application No. 6833/74, Judgment of 13 June 1979, para. 58. See also HunT, "State Obligations Following from a Judgment of the European Court of Human Rights", in CHRISTOU and RAYMOND (eds.), European Court of Human Rights: Remedies and Execution of Judgments, London, 2005, p. $25 \mathrm{ff}$.

${ }^{69}$ HAWKINS and JACOBY, "Partial Compliance: A Comparison of the European and InterAmerican Court for Human Rights", p. 20, available at: <http://www.allacademic.com/meta/ p278931 index.html>.

${ }^{70}$ See, e.g., ECtHR, Papamichalopoulos and others v. Greece (Article 50), Application No. 14556/89, Judgment of 31 October 1995, para. 34.

${ }^{71}$ See, e.g., ECtHR, Broniowski v. Poland, Application No. 31443/96, Judgment of 22 June 2004. The Court summarised its interpretation of Article 46 by holding that it included the obligation: " $[\mathrm{N}]$ ot just to pay those concerned the sums awarded by way of just satisfaction under Article 41, but also to select, subject to supervision by the Committee of Ministers, the general and/or, if appropriate, individual measures to be adopted in their domestic legal order to put an end to the violation found by the Court and to redress so far as possible the effects. Subject to monitoring by the Committee of Ministers, the respondent State remains free to choose the means by which it will discharge its legal obligation under Article 46 of the Convention, provided that such means are compatible with the conclusions set out in the Court's judgment" (para. 192).

${ }^{72}$ See in the Italian legal order Corte di Cassazione, Somogyi, 3 October 2006, No. 32678 (IYIL, Vol. XVI, 2006, p. 317 ff., commentary by PALOMBINo); Corte di Cassazione, Dorigo, cit. supra note 61. Recently, the Corte Costituzionale (Decision No. 113 of 2011, cit. supra note 66) declared the constitutional inconsistency of Article 630 of the Code of Criminal Procedure, insofar as it failed to provide the reopening of domestic criminal proceedings, where it was necessary, pursuant to Article 46(1) ECHR, to comply with a final ruling of the ECtHR. The majority of the Contracting States allow for criminal proceedings to be reopened following judgments of the 
occasions, the Committee of Ministers of the Council of Europe has expressly indicated the national courts as bodies called upon to execute the determinations of the Court. ${ }^{73}$ This action of domestic judges does not exempt, of course, the national legislature from the obligation of adapting the domestic legal system to the European Convention, but it has the merit of preventing further violations.

Finally, the new Protocol No. 14 gives to Contracting States the power to ask the Committee of Ministers to refer to a problem of interpretation of a final judgment to the ECtHR, under Article 46(2) ECHR, before a national court decides on the effect of this final judgment on the domestic law. ${ }^{74}$

Several Member States of the Council of Europe have set up national institutions entrusted with the task of monitoring compliance with the obligations flowing from the European Convention, including decisions of the ECtHR. Particularly, six parliaments - those of Croatia, Finland, Hungary, Romania, Ukraine and the United Kingdom - set up a special body for supervising the implementation of judgments. ${ }^{75}$ Perhaps the most notable of these is the UK Parliamentary Joint Committee on Human Rights, which is generally regarded as a model for other countries to follow. Established in 2001, the Joint Committee is empowered to analyse all government bills and, where it considers that a provision can be improved to better guarantee compatibility with the European Convention, it makes

ECtHR, and a smaller number also allow for the reopening of civil proceedings. The Committee of Ministers has recommended, in its Recommendation on the re-examination or reopening of certain cases at domestic level following judgments of the ECtHR, that Member States should "examine their national legal systems with a view to ensuring that there exist adequate possibilities of re-examination of the case, including reopening of proceedings, in instances where the Court has found a violation of the Convention".

${ }^{73}$ See, i.e Committee of Ministers, Interim Resolution adopted by the Committee of Ministers on 5 July 2005, ResDH (2005)56, concerning the right to an effective remedy against monitoring of prisoners' correspondence and other restrictions imposed on prisoners' rights - general measures in the cases of Messina (No. 2) (Application No. 25498/94, Judgment of 28 September 2000, final on 28 December 2000), Ganci (Application No. 41576/98, Judgment of 30 October 2003, final on 30 January 2004), and Bifulco (Application No. 60915/00, Judgment of 8 February 2005, final on 8 May 2005) against Italy. The Committee specifically addressed Italian authorities with reference to the ECtHR's decisions that ascertained a violation of the right of correspondence (Article 8 of the Convention), inviting them to promptly adopt "the legislative and other measures necessary to ensure prompt and effective judicial review of decisions ordering derogations from the ordinary prison regime or ordering restrictions on prisoners' right to correspondence" and encouraging the domestic courts in particular "to grant direct effect to the European Court's judgments so as to prevent new violations of the Convention, thus contributing to fulfilling Italy's obligations under Article 46 of the Convention".

${ }^{74} \mathrm{~A}$ referral decision requires a majority vote of two thirds of the representatives entitled to sit on the Committee.

${ }^{75}$ See DrZEMCZEWSKI, “The Parliamentary Assembly's Involvement in the Supervision of the Judgments of the Strasbourg Court", NQHR, 2010, p. $7 \mathrm{ff}$. In addition, only 12 of 47 States have procedures in place to inform national parliamentarians of adverse judgments by the ECtHR: Austria, Bosnia and Herzegovina, Croatia, Cyprus, Germany, Hungary, Italy, the Netherlands, Norway, Sweden, Switzerland, and the United Kingdom. 
recommendations that the legislation be remedied to "make the relevant human rights standard explicit". It also reviews the government's response to an adverse judgment of the ECtHR. As part of its work, the Committee may also adopt remedial orders, which are a form of delegated legislation amending primary legislation following a declaration by a UK court that the primary legislation is incompatible with the European Convention or a Strasbourg judgment in a case concerning the United Kingdom.

In practice, a systematic refusal by Contracting States to implement judgments of the ECtHR is rare. The majority of Contracting States try to act in compliance with the European Convention and the judgments of the ECtHR, although it should be noted that some countries have particular difficulty in complying with some judgments against them. ${ }^{76}$

\subsubsection{Expanding the Scope of Article 46(1) ECHR: Effects of Pilot Judgments}

There is no provision in the European Convention which expressly refers to the pilot judgment procedure (PJP). ${ }^{77}$ However, in order to facilitate effective implementation of the European Convention by respondent States, the ECtHR has adopted a PJP which allows the Court to clearly identify, in its judgments, the existence of structural problems underlying the violation of the Convention rights concerned, and to indicate specific measures or actions to be taken by respondent States to remedy them. ${ }^{78}$

The main aim of this procedure is not only to remove the consequences of the unlawful national act for the applicant, but also to induce the respondent State to resolve a large number of individual cases arising from the same structural problem at the domestic level, and thus to offer guarantees of non-repetition. ${ }^{79}$

${ }^{76}$ Recently, for example, in the Resolution 1787 (2011) Implementation of judgments of the European Court of Human Rights, the Parliamentary Assembly of the Council of Europe pointed at Bulgaria, Greece, Italy, Moldova, Romania, The Russia Federation, Turkey, Ukraine and Poland as the countries in which structural problems in implementation of ECHR have arisen. In these States the ECtHR repetitively finds violations of the European Convention in similar cases. In the opinion of the Parliamentary Assembly such a situation seriously undermines the rule of law in the states concerned.

${ }^{77}$ Recently, the PJP has been codified in the new Article 61 of the Rules of Procedure of the ECtHR, which entered into force on 31 March 2011.

${ }^{78}$ See Broniowski, cit. supra note 71, paras. 189-194 and the operative part; and, HuttenCzapska v. Poland [GC], Application No. 35014/97, Judgment of 19 June 2006, paras. 231-239 and the operative part.

${ }^{79}$ On this point, see, among others, Colandrea, "On the Power of the European Court of Human Rights to Order Specific Non-Monetary Measures: Some Remarks in Light of the Assanidze, Broniowski and Sejdovic Cases”, Human Rights Law Review, 2007, p. 396 ff. 
While the respondent State's action is aimed at the resolution of such a dysfunction, the ECtHR may decide to adjourn examination of all similar cases. ${ }^{80}$ However, the ECtHR has held that if the respondent State fails to adopt the measures indicated in the pilot judgment and continues to violate the Convention, the Court would have no choice but to resume examination of all similar pending applications and to take them to judgment so as to ensure effective observance of the Convention rights. ${ }^{81}$

Since the PJP was introduced, the ECtHR has appeared to be increasingly willing to identify systemic problems and to provide guidance to the respondent States, also demanding the introduction of specific remedial measures ${ }^{82}$ and setting deadlines for compliance with the Court's judgments. ${ }^{83}$

In light of this innovative procedure, some scholars emphasize that the PJP is used by the ECtHR as an instrument imposing a "programmed lawmaking obligation" on the domestic legislature, "which is able to substitute the lack [...] of direct effect of the Convention and the lack of erga omnes effect of the Court's judgments in the domestic legal system". 84

In the ECtHR's view, the binding effects of a pilot judgment are based on Article 46 ECHR ${ }^{85}$ The choice of this legal basis has been criticised, ${ }^{86}$ although political

${ }^{80}$ See, i.e. Broniowski, cit. supra note 71, para. 198.

${ }^{81}$ See, i.e. Burdov v. Russia No.2, Application No. 33509/04, Judgment of 15 January 2009, para. 128, and, Olaru and others v. Moldova, Applications Nos. 476/07, 22539/05, 17911/08 and 13136/07, Judgment of 28 July 2009, para. 52.

${ }^{82}$ See, i.e. ECtHR, Suljagic v. Bosnia Herzegovina, Application No. 27912/02, Judgment of 3 November 2009, para. 64.

${ }^{83}$ See, i.e. ECtHR, Burdov cit. supra note 81, para. 141.

${ }^{84}$ See, in particular, FYRNYS, "Expanding Competences by Judicial Lawmaking: The Pilot Judgment Procedure of the European Court of Human Rights", German Law Journal, 2011, p. 1231 ff., p. 1233.

${ }^{85}$ See, i.e. Broniowski, cit. supra note 71, para. 193: "Although it is in principle not for the Court to determine what remedial measures may be appropriate to satisfy the respondent State's obligations under Article 46 of the Convention, in view of the systemic situation which it has identified, the Court would observe that general measures at national level are undoubtedly called for in execution of the present judgment, measures which must take into account the many people affected. Above all, the measures adopted must be such as to remedy the systemic defect underlying the Court's finding of a violation so as not to overburden the Convention system with large numbers of applications deriving from the same cause. Such measures should therefore include a scheme which offers to those affected redress for the Convention violation identified in the instant judgment in relation to the present applicant. In this context the Court's concern is to facilitate the most speedy and effective resolution of a dysfunction established in national human rights protection. Once such a defect has been identified, it falls to the national authorities, under the supervision of the Committee of Ministers, to take, retroactively if appropriate [...], the necessary remedial measures in accordance with the subsidiary character of the Convention, so that the Court does not have to repeat its finding in a lengthy series of comparable cases".

${ }^{86} \mathrm{Criticism}$ regarding the legal basis of the procedure was raised by some ECtHR judges (see Partly dissenting opinion of Judge Zagrebelsky in Hutten-Czapska, cit. supra note 78) and by at 
statements such as the Interlaken Declaration make clear that the procedure has now been accepted, welcomed and encouraged by all Contracting States. ${ }^{87}$

It must be emphasized that the binding effects of pilot judgments are not influenced by whether the indications for State action are included in the merits of the judgment only or also in its operative provisions. Of course, inclusion in the operative provisions increases the legal authority of the judgment. Similarly, the binding effects of pilot judgments are not influenced by whether they are rendered by the Grand Chamber or not. A pilot judgment delivered by a Grand Chamber only has a wider persuasive effect.

Finally, an argument in support of the binding effect of pilot judgments may be drawn from the consideration that a number of PJPs share an a priori recognition by higher courts of respondent States that the existing domestic law or practice concerned violates the European Convention, and that domestic authorities have failed to respond satisfactorily to such findings ${ }^{88}$ Nevertheless, practice shows that the whole PJP depends to a large extent on the respondent State's willingness to cooperate. The cases Broniowksi and Hutten-Czapska showed how different a State's attitude could be in this respect. Whereas in Broniowski the Polish Government was fully willing to cooperate, in Hutten-Czapska the same State contested that a pilot procedure should be used at all.

The ECtHR has held that a respondent State may also adopt remedial measures that are not retroactive. The case Sejdovic v. Italy ${ }^{89}$ is particularly interesting pointing this respect. Indeed, in a first stage before a Chamber, the ECtHR found a violation of the right to a fair trial in the context of in absentia convictions and, in the operative part of the judgment, it established that this violation originated in systemic problems in Italian criminal law and practice. As a result, the ECtHR ordered that Italy should take general measures, going beyond the facts of the particular case. Following this judgment, the respondent State adopted legal reforms in order to comply with the judgment of the Court. However, the new laws did not have retroactive effect on the case of Mr. Sejdovic. In a second stage before the Grand Chamber, although acknowledging the systemic nature of the problem, the ECtHR did not call for general measures, but only noted the reforms adopted by the respondent State and, in the operative part of the judgment, limited itself to finding a violation in the specific case. ${ }^{90}$

least one Government (see ECtHR, Sejdovic v. Italy [GC], Application No. 56581/00, Judgment of 1 March 2006, para. 115), regarding the legal basis of the procedure.

${ }^{87}$ High Level Conference on the Future of the European Court of Human Rights, Interlaken Declaration, 19 February 2010, Action Plan, lett. D.

${ }^{88}$ See i.e. ECtHR, Broniowski (cit. supra note 71), Lukenda v. Slovenia (Application No. 23032/02, Judgment of 6 October 2005), Hutten-Czapska (cit. supra note 78), Scordino v. Italy (No. 1) [GC] (Application No. 36813/97, Judgment of 29 March 2006) and Burdov (No. 2) (cit. supra note 83).

${ }^{89}$ ECtHR, Sejdovic v. Italy, Application No. 56581/00, Judgment of 10 November 2004.

${ }^{90}$ Ibid. 
The Sejdovic case seems to show the importance that the ECtHR attaches to the observance of the non-repetition obligation included in the pilot judgment. However, when the domestic legal reforms implementing the remedial measures do not have retroactive effect, the resumption by the ECtHR of all similar applications pending before it is inevitable.

\subsection{Binding Effects of ECtHR's Interim Measures}

Under Rule 39 of the Rules of Court, the ECtHR has the power to issue interim measures. ${ }^{91}$ As is well known, in the leading case of Mamatkulov ${ }^{92}$ a Grand Chamber ruled on the scope of these interim measures and identified the consequences of a respondent State's failure to respect an order of the ECtHR. In particular, the ECtHR stated that "under the Convention system, interim measures [...] play a vital role in avoiding irreversible situations that would prevent the Court from properly examining the application and, where appropriate, securing to the applicant the practical and effective benefit of the Convention rights asserted". ${ }^{93}$ In these conditions, a failure by a respondent State to comply with interim measures undermines the effectiveness of the right of individual application guaranteed by Article 34 and the State's formal undertaking in Article 1 to protect the rights and freedoms set forth in the European Convention. In addition, in the Olaechea Cahuas case, ${ }^{94}$ the ECtHR clearly considered that a State non-compliance with an interim measure will automatically lead to a violation of Article 34 ECHR, irrespective of the subsequent finding of a violation of other material provisions of the Convention by the ECtHR. ${ }^{95}$

${ }^{91}$ Rule 39 of the Rules of Court empowers a Chamber or, where appropriate, its President, to indicate interim measures. Although the ECtHR receives an increasing number of requests for interim measures, in practice these measures have been indicated only in limited spheres, when there is an imminent risk of irreparable damage for people. The vast majority of cases in which interim measures have been indicated concern deportation, expulsion and extradition proceedings. On this point, see Statement Issued by the President of the European Court of Human Rights concerning Requests for Interim Measures (Rule 39 of the Rules of Court), available at: <http://www.echr.coe.int/NR/rdonlyres/B76DC4F5-5A09-472B-802C-07B4150BF36D/ 0/20110211_ART_39_Statement_EN.pdf $>$. See also SACCUCCI, Le misure provvisorie nella protezione internazionale dei diritti umani, Torino, 2006.

${ }_{92}$ ECtHR, Mamatkulov and Askarov v. Turkey [GC], Applications No. 46827/99 and 46951/99, Judgment of 4 February 2005.

${ }^{93}$ Ibid., para. 125.

${ }^{94}$ ECtHR, Olaechea Cahuas v. Spain, Application No. 24668/03, Judgment of 10 August 2006.

${ }^{95}$ In Paladi v. Moldova (Application No. 39806/05, Judgment of 10 March 2009), the Grand Chamber of the ECtHR stated: "It is for the respondent Government to demonstrate to the Court that the interim measure was complied with or, in an exceptional case, that there was an objective 
The obligation under Article 34 should be strictly and consistently applied. In particular, it requires that the respondent State refrains from taking actions in violation of the interim measure and takes all steps available to comply with the order. A Contracting State cannot substitute its own evaluation for that of the ECtHR in deciding whether or to what extent to comply with interim measures. ${ }^{96}$ The ECtHR said:

\begin{abstract}
"Indications of interim measures [...] permit it not only to carry out an effective examination of the application but also to ensure that the protection afforded to the applicant by the Convention is effective; such indications also subsequently allow the Committee of Ministers to supervise execution of the final judgment. Such measures thus enable the State concerned to discharge its obligation to comply with the final judgment of the Court, which is legally binding by virtue of Article 46 of the Convention". ${ }^{97}$
\end{abstract}

However, Contracting States are reluctant to recognize such binding effects to the decisions on interim measures. On quite a number of recent occasions, the ECtHR has been confronted with cases in which States refused to comply with these interim measures. For example, in the United Kingdom, scholars assert that Section 2(1) of the United Kingdom's 1998 Human Rights Act on domestic judges' obligation to take into account the Strasburg decisions does not apply to interim measures $^{98}$ and, in the Al-Saadoon and Mufdhi case, the UK Government stated "the Government policy to comply with Rule 39 measures indicated by the Court as a matter of course where it is able to do so" ${ }^{99}$ Thus, for some Contracting States compliance with interim measures may be considered as a matter of policy and not as the fulfilment of a legal obligation. For other States, interim measures have binding effects for the case to which they are related and, if well motivated, these measures may be accepted as binding for the domestic authorities as regards other, similar or identical cases, as a judgment of the Dutch Council of State ascertained. ${ }^{100}$

impediment which prevented compliance and that the Government took all reasonable steps to remove the impediment and to keep the Court informed about the situation" (para. 92).

${ }^{96}$ As the Grand Chamber hold in Paladi case: "it is clear from the purpose of this rule, which is to ensure the effectiveness of the right of individual petition [...] that the intentions or reasons underlying the acts or omissions in question are of little relevance when assessing whether Article 34 of the Convention was complied with [...] What matters is whether the situation created as a result of the authorities' act or omission conforms to Article 34" (ibid., para. 87).

${ }^{97}$ ECtHR, Mamatkulov and Askarov v. Turkey, cit. supra note 92, para. 125.

${ }^{98}$ BARRETT, "The Status and Enforceability of Interim Measures of the European Court of Human Rights in English Law: R (Al-Saadoon and Mufdhi) v. Secretary of State for Defence", Judicial Review, 2009, p. 148 ff.

${ }^{99}$ ECtHR, Al-Saadoon and Mufdhi v. United Kingdom, Application No. 61498/08, Judgment of 2 March 2010, para. 81 (emphasis added).

${ }^{100}$ Dutch Council of State (Administrative Law Section), 28 May 2004, available at: $<$ http:// www.raadvanstate.nl> (in Dutch): "Given the general character of the motivation momentarily 
On the matter of the effects of interim measures of the ECtHR in domestic legal orders, a recent ruling by the Italian Court of Cassation is particularly interesting. ${ }^{101}$ The Court of Cassation recognized that interim measures of the ECtHR had broad effects on the basis of arguments expressed by Strasburg judges in Mamatkulov case. In particular, in a case concerning the procedure for expulsion of a Tunisian to his country of origin, the Court of Cassation held that the Italian Government - and any institution of the Italian Republic - must ensure strict compliance with Article 3 ECHR. With regard to the risk inherent in the transfer of an individual to Tunisia, the Court held that a domestic judge has a duty to identify and adopt alternative security measures other than expulsion before ordering the transfer. In addition, the Court of Cassation did not declare that interim measures were only binding in this specific case; there were binding effects for any other domestic measure of expulsion to Tunisia, until it is demonstrated by new facts that individuals expelled in that country will not face imminent risks.

The interpretation of the Court of Cassation seems to go beyond what is formally stated by the ECtHR. In particular, the Italian court seems to recognize that a decision on interim measures has ultra partes effects whenever other cases have factual similarities with the case discussed before the European Court. However, on closer inspection, the Italian court did not build ultra partes effects on the decision on interim measures, but on the binding force of Article 3 ECHR. ${ }^{102}$

The solution adopted by the Italian court seems to envisage that the ultra partes effects of a decision on interim measures can be recognized only in those cases that involved the safeguard of a fundamental value of the Convention, such as the absolute prohibition of torture. In other circumstances, however, it appears that the Court of Cassation did not grant the binding force of interim measures of the ECtHR.

\subsection{Effects of the ECtHR's Case Law}

As has been said, the final judgments of the ECtHR only bind the respondent State. In other words, they do not have effects erga omnes. However, in Ireland v. United Kingdom, the first judgment concerning an inter-State case, the ECtHR stated "The Court's judgments [...] serve not only to decide those cases brought

given for the provisional measure which has been issued - whereby the Section takes into account that the guarantee meant to be present in case of expulsion to Somalia, is momentarily not ensured - it has to be judged that above-mentioned motivated 'interim measure' of the President is yet to be seen as an obstacle to the expulsion to Northern Somalia of foreigners of Somali nationality which belong to a minority and who do not have family or clan bonds in Northern Somalia" (unofficial translation).

${ }^{101}$ Corte di Cassazione, Decision of 28 April 2010, No. 20514.

${ }^{102}$ FORLATI, "Misure cautelari adottate dalla Corte europea dei diritti umani e ordinamento italiano", DUDI, 2010, p. $634 \mathrm{ff}$. 
before the Court but, more generally, to elucidate, safeguard and develop the rules instituted by the Convention, thereby contributing to the observance by the States of the engagements undertaken by them as Contracting Parties (Article 19)". ${ }^{103}$

In doctrine, a dispute exists on the binding effect of ECtHR case law in respect of its interpretative authority (res interpretata). In other words, it is submitted that the case law of the ECtHR reflects the current state of development of the Convention and its Protocols. Some scholars argue that, by failing to take into account the judgments rendered against other States, in certain cases a State could be deemed to be in breach of its duty to fulfil its treaty obligations in good faith. ${ }^{104}$ The interpretative authority of ECtHR's case law seems primarily asserted by the Court itself in decisions on cases struck out of the list because the Court "has already established case-law in the matter" 105 or "it has specified the nature and scope of the obligations undertaken in the matter by the Contracting States" in several previous cases. ${ }^{106}$ On this view, clear and consolidated judgments of the ECtHR would have an interpretative authority.

With the judgment Modinos v. Cyprus, the ECtHR seemed to go further because firstly it observed that the prohibition of male homosexual conduct in private between adults still remains on the Criminal Code of the respondent State and then it criticised a decision of the Supreme Court of Cyprus on this matter "notwithstanding the European Court's Dudgeon v. the United Kingdom judgment of 22 October 1981". ${ }^{107}$ In this case, the Court referred exclusively to its previous judgment on the matter against another State, establishing that the respondent State had violated the Convention.

More recently, in the Interlaken Declaration of 19 February 2010, Contracting States are invited to take into account "the Court's developing case-law, also with a view to considering the conclusions to be drawn from a judgment finding a violation of the Convention by another State, where the same problem of principle exists within their own legal system". ${ }^{108}$ In light of this, a decision of the ECtHR in proceedings against other States Parties may give the States that are not involved an occasion to examine their domestic legal systems and to orient themselves in

${ }^{103}$ ECtHR, Ireland v. the United Kingdom, Application. No. 5310/71, Judgment of 18 January 1978, para. 154.

${ }^{104}$ BARKHUYSEN and VAN EMMERIK, "A Comparative View on the Execution of Judgements of the European Court of Human Rights", in CHRISTOU and RAYMOND (eds.), European Court of Human Rights, Remedies and Execution of Judgements, London, 2005, p. $1 \mathrm{ff}$.

${ }^{105}$ ECtHR, Marlhens v. France, Application No. 22862/93, Judgment of 24 May 1995.

${ }^{106}$ ECtHR, Clerc v. France, Application No. 12393/86, Judgment of 26 April 1990. 20.

${ }^{107}$ ECtHR, Modinos v. Cyprus, Application No. 15070/89, Judgment of 22 April 1993, para.

${ }^{108}$ High Level Conference on the Future of the European Court of Human Rights, Interlaken Declaration, 19 February 2010, Action Plan, lett. C. See also ZAGREBELSKY, "La Conferenza di Interlaken per assicurare l'avvenire della Corte europea dei diritti umani”, DUDI, 2010, p. 309 ff. 
light of the relevant case law. This would reinforce the States' obligation to prevent Convention violations. However, experience has shown that there is a lack of uniformity among the Contracting States when it comes to recognising the authority of the case law of the ECtHR. We can observe at least two main tendencies on this point in Contracting States' legal orders.

Firstly, there is the model of the United Kingdom's 1998 Human Rights Act. Section 2(1) of this Act specifies that national courts "must take into account" any "judgment, decision, declaration or advisory opinion" of the ECtHR. ${ }^{109}$ Similarly, Article 17 of the Ukrainian Law on the Enforcement of Judgments and the Application of the Case-Law of the European Court of Human Rights ${ }^{110}$ establishes: "Courts shall apply the Convention [ECHR] and the case-law of the [Strasbourg] Court as a source of law". In the United Kingdom, for instance, it is the duty of domestic courts to give effect to the principles laid down by the Strasbourg Court as governing the Convention rights which the domestic court thinks are relevant to the Convention issue which it has to decide. A court is not strictly required to follow Strasbourg rulings; but if it acts in a manner incompatible with a Convention right, it acts unlawfully. ${ }^{111}$ However, under this approach, it must be underlined that it is often very difficult to determine the exact implications of the ECtHR's case law for a national legal system.

Due to the growing number of Strasbourg judgments, it is becoming increasingly difficult to follow and analyse the actual state of the case law; thus, national judges have begun to differentiate between judgments of the Court decided by a single judge, those decided by panels of three judges, by Chambers of seven judges, and by a Grand Chamber of seventeen. Finally, the need to take into account the Strasbourg jurisprudence normally is guaranteed in national courts applying principles that are clearly established by the ECtHR, especially those established by Grand Chambers.

Nevertheless, there are disadvantages in this approach that takes into account the Strasbourg jurisprudence. It does not, for example, acknowledge that the ECtHR is only laying down minimum guarantees. A close adherence to Strasbourg jurisprudence has also been criticized as preventing domestic courts from developing

${ }^{109}$ See also in Irish legal order, the European Convention on Human Rights Act 2003, Section 4: "Judicial notice shall be taken of the Convention provisions and of $(a)$ any declaration, decision, advisory opinion or judgment of the European Court of Human Rights established under the Convention on any question in respect of which that Court has jurisdiction, [...], and a court shall, when interpreting and applying the Convention provisions, take due account of the principles laid down by those declarations, decisions, advisory opinions, opinions and judgments".

${ }^{110}$ Law No. 3477-IV of 23 February 2006.

${ }^{111}$ House of Lords, Opinions of the Lords of Appeal for Judgment in the Cause Kay and others and another (FC) (Appellants) v. London Borough of Lambeth and others (Respondents) Leeds City Council (Respondents) v. Price and others and others (FC) (Appellants), 8 March 2006, [2006] UKHL 10, para. 28. See AMOS, "The Principle of Comity and the Relationship between British Courts and the European Court of Human Rights", YEL, 2009, p. $503 \mathrm{ff}$. 
an independent role in interpreting the ECHR. Indeed, on the basis of the European Convention, the ECtHR does not have an exclusive interpreting role: national courts could have an independent role. ${ }^{112}$ More fundamentally, this attitude toward close adherence to Strasbourg jurisprudence means that it is difficult to have an effective dialogue between ECtHR and national courts. The majority of courts in the Contracting States do not take the view that they are effectively bound by Strasbourg jurisprudence. But there are a growing number of examples in the practice of States suggesting that the interpretative authority of the ECtHR is currently increasing. ${ }^{113}$ In these jurisdictions, there are usually written Constitutions including a domestic Bill of Rights, so that precedence can be given to the rights contained in the Constitution. Thus, the application of the case law of the ECtHR in national legal systems is moderated by the exception of the case of non-compliance of the judgments with the fundamental principles of the national constitutional system.

In Germany, for instance, national authorities and courts are under an obligation to take into account the decision of the ECtHR in the domestic sphere, which means "taking notice of the Convention provision as interpreted by the ECtHR and applying it to the case, provided the application does not violate prior-ranking law, in particular constitutional law". ${ }^{114}$ However, according to the Federal Constitutional Court, there is a further possibility of non-compliance with the rulings of the ECtHR. It concerns the execution of judgments of the ECtHR in the context of national litigation which needs to strike a balance between the numerous diverging interests of the parties concerned and is characterised by "multipolar legal relations connected with fundamental rights", ${ }^{115}$ as is often the case, for instance, in family law and the protection of personality rights. ${ }^{116}$

${ }^{112}$ See CANNIZZARO, cit. supra note 58, p. 183; NOLLKAEMPER, cit. supra note 58, pp. 196197.

${ }^{113}$ See, i.e. some recent decisions of national courts that refer to the decisions of the ECtHR, which did not involve their States. Belgium: Cour de Cassation de Belgique, arrêt, P.09.0547.F/1, 10 June 2009; Cyprus: Yiallourou v. Evgenios Nicolaou, Judgment of 8 May 2001, Civil Action No. 9931; FYROM: Bitola Court of Appeal, Case No. 232/2008; Russia: Supreme Court, Judgment 21-Г10-2 of 27 July 2010; Switzerland: Federal Court Decision ATF 131 (2005) 455; Turkey: Constitutional Court of Turkey, Judgment No. 2003/33 of 10 April 2003.

${ }_{114}$ BVerfGE 111, 307, cit. supra note 22, para. 62. See further PAPIER, "Execution and Effects of the Judgments of the European Court of Human Rights from the Perspective of German National Courts", HRLJ, 2006, p. 1 ff.; TOMUSCHAT, "The Effects of the Judgments of the European Court of Human Rights According to the German Constitutional Court", German Law Journal, 2010, p. $513 \mathrm{ff}$.

${ }^{115}$ BVerfGE 111, 307, cit. supra note 22, para. 50.

${ }^{116}$ See comments of PAPIER (President of the German Federal Constitutional Court), "Execution and effects of the judgments of the European Court of Human Rights in the German judicial system", in Dialogue Between Courts, European Court of Human Rights, Council of Europe, Strasburg, 2006, available at: <http://www.echr.coe.int/NR/rdonlyres/368D4336-51504F83-86A1-18957F0F778E/0/Dialogue_between_judges_2006.pdf $>$ : "In our opinion, a mechanical execution of the ECHR's judgment in such cases is out of the question because, due to the nature of an individual application to the ECHR, which confers the capacity of party to the 
In Austria, the European Convention enjoys constitutional rank and Austrian courts, especially the Constitutional Court, cite regularly and extensively Convention articles as well as Strasbourg jurisprudence. However, already in its 1987 Miltner judgment the Constitutional Court made it clear that there would be limits to its adherence to Strasbourg judgments, and if the ECtHR pushed its interpretative function too far, it would not be able to follow it. ${ }^{117}$ This judgment has not yet been overturned.

\subsubsection{Effects of the ECtHR's Case Law and the Approach of the Italian Constitutional Court}

An interesting approach on the question of the effects of the case law of the ECtHR is provided by the recent jurisprudence of the Italian Constitutional Court.

As argued above, the jurisprudence of the Italian Constitutional Court has clarified that Article 117(1) of the Constitution must not be seen as recognising a hierarchical superiority of the European Convention rules over the Constitution. The Court describes a system in which constitutional rules will have to be interpreted in line with the European Convention as interpreted by the ECtHR when the Convention provides a higher standard of protection for human rights than the system of constitutional rights protection. ${ }^{118}$ Finally, the jurisprudence of the Corte Costituzionale took a step further in recognizing that the interpretation of the European Convention by the Strasbourg Court had binding effect and that Italian courts could not therefore adopt interpretations of the Convention that diverge from those of the ECtHR. The Court based its view on the consideration that, under Article $32 \mathrm{ECHR}$, the ECtHR is charged with the role of interpreting the provisions of the Convention. ${ }^{119}$

The view of the Corte Costituzionale on this point seems to be too far-reaching. The binding effect of the ECtHR's case law within the domestic legal order was not explicitly provided for by Article 32 ECHR, which only described the scope of jurisdiction of the ECtHR. Admittedly, final judgments rendered in cases in which Italy is a respondent State are formally binding upon it. However, in all other cases the weight to be given to the ECtHR's case law varies depending on

proceedings only to the applicant and the respondent State, such execution cannot do equal justice in every case to the conflicting interests of the various parties in the national litigation".

${ }^{117}$ Austrian Constitutional Court, Miltner, 14 October 1987, VfSlg 11500/1987, available at: $<$ http://www.ris.bka.gv.at/Vfgh>.

${ }^{118}$ Corte Costituzionale, Judgments Nos. 348 and 349 of 2007, cit. supra note 46. See the references ibid.

${ }^{119}$ Corte Costituzionale, Judgment No. 317 of 2009, cit. supra note 55. See CANNIZZARO, "Il bilanciamento fra diritti fondamentali e l'art. 117, $1^{\circ}$ comma, Cost.", RDI, 2010, p. 128 ff.; NAPOLETANO, cit. supra note 46, p. 194 ff.; Corte Costituzionale, FV, 4 December 2009, Judgment No. 317, English excerpts and commentary by CALIGIURI, International Law in Domestic Courts, ILDC 1491 (IT 2009). 
the circumstances. Thus, when a certain interpretation by the ECtHR is supported by settled jurisprudence or by recent judgments of the Grand Chamber, little room is left to domestic courts for the adoption of a different interpretation: in such cases, deviation from an established interpretation may amount to a violation of the European Convention.

The situation is different when a specific interpretation of the Convention is merely supported by old decisions of the ECtHR or, more generally, by a decision which does not reflect the established case law of the ECtHR. While all of the ECtHR's decisions obviously have the same formal value, it may be held that national courts would be justified if they accorded less deference to certain decisions because of the time elapsed since their adoption or because they do not form part of an established jurisprudence. National courts, by adopting a novel interpretation, may play an important role in persuading the ECtHR to clarify or change its jurisprudence. Conversely, the rigid view adopted by the Corte Costituzionale implies that domestic courts will be able to influence the interpretation of the European Convention only in cases in which the ECtHR has not already interpreted particular European Convention rules. Such cases are likely to be quite rare.

The decision of the Corte Costituzionale touches upon the issue of the dialogue between the ECtHR and national courts. Such a dialogue seems desirable insofar as it can promote a dynamic interpretation of the European Convention, as a result of which a higher level of human rights protection might be attained.

\subsubsection{Final Remarks on the Active Role of the Contracting States as regards the Interpretation of the European Convention}

In conclusion, the practice of Contracting States provides numerous examples of how well-regarded the interpretative authority of the ECtHR is by their domestic courts. This approach leaves national judges free to develop an independent interpretation of the European Convention on the basis of classic international rules on the interpretation of treaties. Even the strict UK legal system leaves domestic judges little room for interpreting the European Convention. Recently, in In re P case, the House of Lords has decided on a case of interpretation of the concept of discrimination on grounds of marital status as regards eligibility for adoption, in the absence of ECtHR case law on this issue. In this case, the majority agreed that "section 2(1) of the 1998 Act allows for the possibility of a dialogue between Strasbourg and the courts of the United Kingdom over the meaning of an article of the Convention but makes this likely to be a rare occurrence". ${ }^{120}$

${ }^{120}$ House of Lords, In re P and others, cit. supra note 26, Opinion of Lord Hoffman, para. 35 . 
Thus, a very important means of dialogue is through judgments. In fact, through its judgments, a national court can send a message to the ECtHR, which reflects its interpretation of the European Convention, and thus influence the direction of the jurisprudence of the ECtHR.

The ECtHR is not bound to accept what national courts say, but in the Roche case it has gone a long way towards recognising the role of superior national courts. ${ }^{121}$ On this basis, the ECtHR could be willing, in specific cases, to depart from its previous case law in light of disagreement expressed by a superior national court.

The dialogue between national legal systems and the conventional system is the only means which seems able to ensure a high standard of protection of human rights in Europe. It must be borne in mind that the conventional system ensures the lowest common denominator of protection of rights. This minimum standard may be raised by the ECtHR only through an evolutionary interpretation taking into account the principles established in the most advanced protection systems of some Contracting States.

Another type of dialogue between the ECtHR and the national legal systems could be used. Contracting States should take due notice of the developments in the ECtHR's case law, because they might have a direct interest in the outcome of cases against other States. They should also intervene as third parties (Article 36 ECHR) to serve their interests, as many countries did, for example, in the case of A. v. United Kingdom on parliamentary immunities ${ }^{122}$ or in the case Lautsi v. Italy on the crucifix. ${ }^{123}$ Furthermore, each State could play an important role in pushing the ECtHR to clarify or change its leading jurisprudence, for example by proposing that it should take national case law into account.

Finally, the best way to build a stable form of dialogue between ECtHR and national courts would be to "reflect on the advisability of introducing a procedure allowing the highest national courts to request advisory opinions from the [European] Court". ${ }^{24}$

${ }^{121}$ ECtHR, Roche v. United Kingdom, Application No. 32555/96, 19 October 2005, para. 120: "Where $[\ldots]$ the superior national courts have analysed in a comprehensive and convincing manner the precise nature of the impugned restriction, on the basis of the relevant Convention case-law and principles drawn therefrom, this Court would need strong reasons to differ from the conclusion reached by those courts by substituting its own views for those of the national courts on a question of interpretation of domestic law [...] and by finding, contrary to their view, that there was arguably a right recognised by domestic law".

${ }^{122}$ ECtHR, A v. United Kingdom, Application No. 35373/97, 17 December 2002.

${ }^{123}$ ECtHR, Lautsi v. Italy [GC], Application No. 30814/06, 18 March 2011.

${ }^{124}$ High Level Conference on the Future of the European Court of Human Rights, Izmir Declaration, 27 April 2011. 
